\title{
Assessment of Personnel and Consumer Orientation in the Realization of Value Development of Services
}

\author{
Valeeva Julya Sergeevna \\ Kazan State Power Engineering University \\ Kazan, Russia \\ Valis2000@mail.ru \\ Nurtdinov Ilgiz Irekovich \\ Kazan State Medical University \\ Ilgiz2010@mail.ru \\ Shargu Lilia Stepanovna \\ University of European Studies of Moldova \\ Kishiniv, Moldova \\ lshargu@list.ru
}

\author{
Ilikova Liliya Ernstovna \\ Kazan Federal University \\ Kazan, Russia \\ liliaernst@mail.ru
}

\author{
Ignatev Vladimir Georgievich \\ Kazan National Research Technological University \\ Kazan, Russia \\ wg__@mail.ru
}

\author{
Chkalova Olga Vladimirovna \\ Lobachevsky State University of Nizhny Novgorod \\ Nizhni Novgorod, Russia \\ Chkalova63@mail.ru
}

\begin{abstract}
Assessment of personnel and consumer orientation in the realization of value development of services

In the context of realization of value service development for network-based enterprises, which include retail chains, corporate standards are necessary. The article justifies that a clear regulation of labour processes will ensure staff and consumer orientation through the allocation of functions and responsibilities among officials based on value management.

Interviews with key employees and completion of questionnaires of consultant sellers and cooks in supermarkets were used as methods of conducting the study. The proposed methodology of evaluation of efficiency of organization of labor processes of retail chains using three factors (types of works performed, complexity of works, time of works performance) compiled in accordance with UTQD (Unified tariff-qualification directory of works and professions of workers), and interviews with managers.

The analysis on the developed method of labor peculiarities in terms of positions of working professions on the example of the three largest trading chains in Moscow and Kazan allowed to determine the performance of the system of motivation and loyalty.

The results of the analysis are presented taking into account various factors and main groups of works performed, labor operations are identified in accordance with UTQD, clarified and agreed with the administrators of the market and questionnaires and working instructions of sales consultants are prepared. The results of the organization of labour processes formed the basis of
\end{abstract}

the constituent elements of corporate service standards for the studied trade chains, which develop a strategy of client-oriented development.

Keywords: client orientation of consumers, value-based development, retail chains

\section{INTRODUCTION}

Trade, as a separate market area, operates in specific market conditions. As an important link in the value chain, traders are directly involved in the process of goods movement from producer to consumer. The competition of trading companies for market share, sales volumes and eventually for the buyer, forces trading organizations to look for new innovative ways of business development. Innovation provides retailers not only with additional profit by reducing the cost of circulation, improving the quality of trading services, but also allows to increase the competitiveness of trading companies, forming a building away from competitors, increasing loyalty of buyers [1-5] 
During the process, considerable time is spent on negotiation of contracts, excessive subordination among sales management leads to loss of time, queues, loss of loyalty of clients. We are asked to evaluate the work of competitors with consumers; To reengineering all processes organized worse than in competing organizations, to direct the work of own personnel to the client and his needs.

The study carried out by the authors revealed that in order to estimate the level of client orientation in the human resources management system, it is necessary to use three indicators for analysis: types of works performed, complexity of works, time of work performance. Application of these indicators, in our opinion, will allow to form a reasonable functionality of employees taking into account a single tariff and qualification guide of works and professions, peculiarities of development of trade organization services and labor intensity, as well as to develop rules of interaction of employees. It is possible to achieve increased efficiency of retail network service through implementation of principles of process approach, clear distribution of functions and responsibility among officials [15-16].

In 2017-2018, the author of the dissertation study analyzed the peculiarities of work in terms of positions and working professions, as well as the effectiveness of the motivation and loyalty system in few of trading chains in Moscow and Kazan.

The aim of the study was to assess the severity of labor costs and client orientation, to analyze the labor operations performed by professions seller-consultant and cook of culinary production in the trading networks "Bahetle", "Edelweiss", "Carousel", Magnet", located in Kazan and Moscow ("Taste ABC"), to determine the correction factor for the labor intensity of the analyzed professions and the average labor market.

Interviews with key staff and the completion of questionnaires of consultants and cooks in "Bahetle" supermarkets and retail chains were used as methods of conducting the study. The analysis of the performed labor operations by professions of the seller-consultant and cook of culinary production was carried out on the basis of the analysis of questionnaires prepared in accordance with UTQD (Unified tariff-qualification directory of works and professions of workers), and interviews with managers.

The calculation method for the "Types of work performed" criterion was that the questionnaire of a particular seller was compared to the questionnaire of the seller selected as the sample (reference), the number of types of work performed by the seller according to a particular grade in the sample was determined, and the percentage of work performed for each grade was calculated. [17]

\section{RESULTS}

The results of the analysis of labor operations performed by profession are presented by the consultant seller of the supermarket "Bahetle" taking into account various factors and the main groups of work performed. Main groups of works performed by sales consultants at the "Bahetle" supermarket:

- Service of buyers; 
largest amount of time is devoted to the types of work corresponding to the qualification of the seller of the 2 category (67\% working time).

In the structure of working time of the seller of the 4 category freezing department, acting as a brigadier, the senior seller of the alcohols department, the most time is spent on performance of works of the seller of the 2 category $(57.2 \%$ and $77.8 \%$ respectively). The 3 category vegetable department sellers also spend most of their time (82.5 and $91 \%$ respectively) performing the 2 category seller's work.

The study made it possible to draw the following conclusions.

1. The assigned grade to sellers is conditional, as in fact sellers of different departments perform works of different qualifications, including types of works corresponding to the qualifications of the kitchen worker of the 2 category.

2. In the structure of working time expenses, the largest share of time is occupied by works corresponding to the qualification of the 2 category seller.

3. The types of jobs of the seller of the 2 category are perceived by the survey participants as the most complex (more than 5 points on the 10-point scale), although in general the seller's work is not perceived by the survey participants as complex (the average value of 3.72 points on the 10-point scale). below.

The results of the survey of "Bahetle" cooks are presented categories, as well as the employees of the market, have statistically significant differences. The greatest variety in the types of works performed in all ranks is observed in the work of the seller of the 4, who simultaneously performs the functions of a brigadier. In the work of sellers, the largest percentage is the types of work corresponding to the 2 category.

This percentage varies from $50 \%$ for a delicacies employee to $87.5 \%$ for a 3 category vegetable seller and a alcohols seller. On average, the types of work corresponding to the qualifications of the 2 category seller are 67.2\%. Types of work of 3 and 4 category have values lower, compared to works of 2 category (64.3 and $46.44 \%$. respectively). The "Bahetle" supermarket sellers also perform the types of work appropriate to the kitchen worker, an average of $56.3 \%$.

The method of calculation of the "Work complexity" criterion was to determine the average value of work complexity for each grade (non-replenished works were not taken into account). According to the sellers, all types of works performed by them are not perceived as complex and on a 10-point scale are rated from 2,1 points (types of works of the kitchen worker) to 5.2 points (types of works of the sellers of 2 categories). As the most difficult seller - brigadier of the 4 category allocates additional types of works and estimates in 8.5 points. For the seller of the 2 category of the freezing department, the most difficult works are those corresponding to the 3 and 4 category.

The calculation method for the factor "Time spent on work execution" consists in calculation of the amount of time spent on work performance of a certain grade (time in \%) The
TABLE I. COMPARATIVE ASSESSMENT OF THE LEVEL OF WORK PERFORMED BY THE "SELLER-CONSULTANT" PROFESSION.

\begin{tabular}{|l|l|l|l|l|}
\hline $\begin{array}{c}\text { Retail chain / } \\
\text { factors }\end{array}$ & $\begin{array}{c}\text { Types } \\
\text { of } \\
\text { works }\end{array}$ & $\begin{array}{c}\text { Complexity of } \\
\text { works }\end{array}$ & $\begin{array}{c}\text { Time Spent } \\
\text { for performance } \\
\text { of works }\end{array}$ & $\begin{array}{c}\text { Correction } \\
\text { factor }\end{array}$ \\
\hline $\begin{array}{l}\text { "Bahetle"/ } \\
\text { "Carousel" }\end{array}$ & 1.53 & 0.58 & 0.91 & 1.01 \\
\hline $\begin{array}{l}\text { "Bahetle"/ } \\
\text { "Edelweiss" }\end{array}$ & 0.83 & 1.02 & 1.17 & 1.01 \\
\hline $\begin{array}{l}\text { "Bahetle"/ } \\
\text { «Magnit» }\end{array}$ & 0.95 & 1.01 & 1.08 & 1.02 \\
\hline $\begin{array}{l}\text { "Bahetle" } \\
\text { «Essen» }\end{array}$ & 1 & 0.80 & 1.23 & 1.01 \\
\hline $\begin{array}{l}\text { "Bahetle"/ } \\
\ll \text { Taste ABC» }\end{array}$ & 1.64 & 0.81 & 1.04 & 1.06 \\
\hline Total coefficient & & & & 1.17 \\
\hline
\end{tabular}

The results of the survey of sellers of the network "Taste $\mathrm{ABC}$ " show that the system of motivation, is represented by two parameters:

1. Quantitative indicators: implementation of the plan for a trade turnover of the organization and for personal, personal sellings (countertop trade of network makes $70 \%$ of a turnover of supermarket).

2. Qualitative indicators: implementation of customer service standards, including maintaining the quality of the sold 
indicators in 2014, the profitability of personnel increases annually: during the analyzed period from 2014 to 2018 it increased from 4.46 p.p. Positive is the increase of return of expenses by 2.07 points, which also testifies to the efficiency of the trade process. However, productivity indicators should be monitored. In retail, in retail chains, it's an average check per merchant. Productivity growth can be achieved through emerging and rapidly evolving new trade formats. Today, they already account for $35 \%$ of retail sales, with $11 \%$ of the sector 's involvement.

To this end, we will calculate the profitability of the wage fund, trade activities and quality of work in table II.

TABLE II. BAHETLE" TRADE CHAIN PERFORMANCE ESTIMATES

\begin{tabular}{|l|l|l|l|l|l|l|l|}
\hline Name of indicator & $\mathbf{2 0 1 2}$ & $\mathbf{2 0 1 3}$ & $\mathbf{2 0 1 4}$ & $\mathbf{2 0 1 5}$ & $\mathbf{2 0 1 6}$ & $\mathbf{2 0 1 7}$ & $\begin{array}{l}\text { Average } \\
\text { value }\end{array}$ \\
\hline $\begin{array}{l}\text { Level of salary fund } \\
\text { profitability,\% }\end{array}$ & 18 & 19 & 21 & 22 & 22 & 22 & 22.31 \\
\hline $\begin{array}{l}\text { Level of profitability of } \\
\text { trade organization } \\
\text { activity.\% } \%\end{array}$ & 2.5 & 2.6 & 2.4 & 2.3 & 1.3 & 2.14 \\
$\begin{array}{l}\text { Quality of work (p.2/p } \\
1 * 100)\end{array}$ & 8.8 & 8.4 & 9.1 & 9.8 & 16 & 10.4 \\
\hline
\end{tabular}

From the table of calculations of labor quality of sales personnel we can understand that it does not meet modern requirements of the labor market. Professional requirements for the qualification of employees and their quality of work are being tightened. It follows from the analysis that on average only one in 8 to 9 employees increases the profitability of the trading activities of the retail chains.

The system of standardization of labor processes and material motivation proposed by us for implementation in "Bahetle", first, forms a sufficient level of wages, assesses personal and professional qualities of personnel. Second, it forms a new level of development of labor relations. Third, reduces the typical turnover of sales personnel. Therefore, as a result, it was proposed and introduced an increase in the average salary of sellers and cooks, defined a clear functionality of employees, which allows to adhere to a certain standard of service.

As a result of the implementation of the system of standardization of labor processes and material motivation, the connection of incentive measures with the economic stability of trading enterprises of the retail chains under study is increased. The projected average wage will increase by $15.9 \%$ and profit by $4 \%$. The profitability of retail chains will increase by 1.96 p.p.

\section{CONCLUSIONS}

In 2018, as a proposal, a staff motivation system linked also to the employee's personal contribution was introduced into the activities of the "Bahetle" trading chain. Modern technologies allow you to record the level of sales of each department daily with the help of the modernized SAB program and expert way of senior managers. Accordingly, the more goods from this department were sold, the higher the premium part of the salary of the employees of the

The factor analysis determined that productivity growth is directly related to increased customer orientation. In addition 
distinctive point of the presented work compared to other approaches to organization of retail chains efficiency.

The work highlighted three types of motivation, including material motivation, self-motivation and direct material motivation or intangible motivation. It has been established that a feature of resource labor processes in retail is their dependence on efficiency and loyalty.

We offer the following activities to improve the efficiency of retail services.

\section{REFERENCES}

[1] B. Hallier, "Modern Stores: A History of Technical Development", 2009, $184 \mathrm{p}$.

[2] I. A. Krasyuk, S. M. Krymov, Y. Y. Medvedeva, A. M. Chernisheva and S. I. Lashko, "Marketing Management in Retail Chains", International Journal of Applied Business and Economic Research, 2017, vol. 15, no. 12, pp. 83-91.

[3] I. A. Krasyuk, V. V. Bakharev, and Y. Y. Medvedeva, "Sector specific features of innovative development in the Russian econom y", SHS Web of Conferences 2017, 35, 01052.

[4] I. A. Krasyuk, T. V. Kirillova, and N. A. Kozlova, " Network technologies as innovative solution in commodity circulation", SHS Web of Conferences, 2017, 35, 01055.

[5] D. V. Shkurkin, I. A. Krasyuk, S. M. Krymov, I. G. Kazantseva, and G. Zakharenko, "Sales Policy and Sales Marketing System", International Journal of Applied Business and Economic Research, 2017, vol. 15, no. 12, pp. 203-213.

[6] C. H. Coombs, R. M. Dawes, and A. Tversky, "Mathematical Psychology: An Elementary Introduction", N. J., Englewood Cliffs: Prentice-Hall, 1970.

[7] W. S. Torgerson, "Multidimensional Scaling: Theory and Method", Psychometrica, 1952, vol. 17, no. 4, 401419 p.

[8] R. N. Shepard, "The Analysis of Proximities: Multidimensional Scaling with an Unknown Distance Function. II", Psychometrica, 1962, vol. 27, no. 3, $219246 \mathrm{p}$

[9] E. T. Sokolova, "Portability - intolerance of uncertainty: sociocultural, differential-psychological, clinical aspects", Annual of RPO, M, 2005, pp. 422-423.

[10] J. Bruner, R. Olver, and P. Greenfield, "Study of Cognitive Development", Under Ed. P, Greenfield, M, 1971.

[11] O. Oyner and A. Korelina, "The influence of customer engagement in value co-creation on customer satisfaction Searching for new forms of cocreation in the Russian hotel industry", Worldwide Hospitality and Tourism Themes, 2018, vol. 8, no. 3, pp. 327-345.

[12] D. Grewal, K. B. Monroe, and R. Krishnan, "The Effects of PriceComparison Advertising on Buyers' Perceptions of Acquisition Value, Transaction Value, and Behavioral Intentions", The Journal of Marketing, 2018, vol. 62, no. 2, pp. 46-59.

[13]N. Sharafutdinova and J. Valeeva, "Quality management system as a tool for intensive development of trade organizations", Mediterranean Journal of Social Sciences, 6 (1S3), $498 \mathrm{p}$.

[14]O. N. Dolinina, V. A. Kushnikov, V. V. Pechenkin, and A. F. Rezchikov, "The way of quality management of the decision making software systems development", In: Silhavy, R. (ed.) Software Engineering and Algorithms in Intelligent Systems CSOC 2018, 2018, Advances in Intelligent Systems and Computing, Springer, Cham. 2019, vol. 763, pp. 90-98. DOI: https://doi.org/10.1007/978-3-319-91186-1_11.

[15]E. I. Shangina, "The triad of vitruvius in the modern world. In: Cocchiarella", Proceedings of the 18th International Conference on Geometry and Graphics, ICGG 2018, Advances in Intelligent Systems and Computing, Springer, Cham, 2019, vol. 809, pp. 2095-2107. DOI: https://doi.org/10.1007/978-3-319-95588-9_187. 
[16]O. A. Kozlova, E. V. Sukhostav, N. A. Anashkina, O. N. Tkachenko, E. Shatskaya, "Consumer model transformation in the digital economy era", In: Popkova, E., Ostrovskaya, V. (eds.), Perspectives on the Use of New Information and Communication Technology (ICT) in the Modern Economy, ISC 2017, Advances in Intelligent Systems and Computing, Springer, Cham, 2019, vol. 726, pp. 279-287. DOI: https://doi.org/10.1007/978-3-319-90835-9_33

[17]L. Thomas, "This chart shows how quickly Amazon is 'eating the retail world", CNBC, 2017 [Electronic resource]. Available at: https://www.cnbc.com/2017/07/07/amazon-is-eating-the-retailworld.html (Accessed: 2 February 2019).
Management mit digitalen Tools", Springer Gabler, Wiesbaden, Springer Fachmedien Wiesbaden GmbH, ein Teil von Springer Nature 2018. DOI: https://doi.org/10.1007/978-3-658-22331-1.

[19]E. S. Rolbina, E. N. Novikova, N. S. Sharafutdinova, and O. V. Martynova, "The study of consumer loyalty services", Ad AltaJournal of Interdisciplinary Research, 2017, vol. 7, is.2, pp. 248-253.

[20] Y. Liu, A. Liu, X. Liu, and X. Huang, "A statistical approach to participant selection in location-based social networks for offline event marketing Information", Sciences, 2019, vol. 480, pp. 90-108. DOI: https://doi.org/10.1016/j.ins.2018.12.028. 